\title{
Anti-0xidative Stress Enzyme from Pleurotus sp
}

\author{
Vikas Kaushal ${ }^{1}$, Vikram Thakur ${ }^{1}$, Manoj Kumar ${ }^{2}$ and Arvind Kumar Bhatt ${ }^{1 *}$ \\ ${ }^{1}$ Department of Biotechnology, Himachal Pradesh University, India \\ ${ }^{2}$ Department of Virology, Shoolini University, India
}

Submission: June14, 2018; Published: August 31, 2018

*Corresponding author: Arvind Kumar Bhatt, Department of Biotechnology, Himachal Pradesh University, Shimla (HP), Pin-171005, India;

Tel: 9418276448; Email: bhtarvind@yahoo.com

\begin{abstract}
Pleurotus sp. known for its medicinal values and considered as king of all edible mushrooms. Three species of oyster mushrooms (Pleurotus spp.) that are cultivated mostly throughout the year in the plains of India were studied for their antioxidant properties with few modifications like ultra-sonication and standardizing various factors like solvent, buffer, $\mathrm{pH}$, time, incubation time and enzyme concentration. Using buffer extraction/homogenization, there was remarkable increase (increase of two-fold) in enzyme activity from 13.35 to $26.70 \mathrm{U} / \mathrm{mg}$ in Pleurotus djamor var. roseus, 8.47 to $19.05 \mathrm{U} / \mathrm{mg}$ in P. ostreatus and 11.74 to $22.12 \mathrm{U} / \mathrm{mg}$ in P. florida after ultrasonication which has not been reported earlier while using different solvents i.e. Methanol, ethanol, and water. Maximum inhibition was observed in natural extract (96.38\%), followed by buffer $(91.84 \%)$ and ethanolic extract $(91.74 \%)$. Comparative efficiency of homogenization of mushroom samples in buffer system with or without ultrasonication was evaluated, that has not been reported earlier for study of antioxidative stress enzymes in Pleurotus species. Maximum SOD $(26.70 \mathrm{U} / \mathrm{mg})$ and POX $(0.51 \mathrm{U} / \mathrm{ml})$ was recorded at $\mathrm{pH} 6.0$ (potassium phosphate buffer, $1 \mathrm{M})$ with P. djamor var. roseus and $(22.12 \mathrm{U} / \mathrm{mg})$ and $(0.39 \mathrm{U} / \mathrm{ml})$ for P. Florida (phosphate citrate buffer, $\mathrm{pH} 6.5)$. Optimum SOD $(29.95 \mathrm{U} / \mathrm{ml})$ and POX $(0.63 \mathrm{U} / \mathrm{ml})$ activity for P. djamor var. roseus was reported at $40{ }^{\circ} \mathrm{C}$ and $37^{\circ} \mathrm{C}$ respectively at different time of incubation. Though the anti-oxidative stress enzymes could make a significant contribution to the antioxidant activity in these edible mushroom extracts, yet the chemical characteristics of these components are required to be investigated.
\end{abstract}

Keywords: Pleurotus; Antioxidant; Superoxide dismutase; Peroxidase; Ultra-sonication; Mushrooms; Pleurotus species; P Florida; P djamor var; Homogenization; Methanol; Ethanol; Water; Superoxide dismutase; Ostreatus

\section{Mini Review}

Pleurotus (edible mushroom) widely consumed globally has been reported to possess good antioxidant activity [1]. Pleurotus are reported to be a good source of cysteine, methionine and aspartic in comparison to Agaricus bisporus (brown, white) and Lentinus edode [2] and bioactive compounds (Phenolic, terpenes, polyketides) [3]. In addition, Pleurotus species reported to possess excellent free radical scavenging and therapeutic potential (Levostatin) for treating hypercholesterolemia [4]. Pleurotus extracts could be used in the treatment of infections commonly associated with the micro -organisms and in treatment of skin diseases. Among various species of Pleurotus, Pleurotus djamor var. roseus has remained less studied till now, definite its use as potent mushroom. Efforts made in past to study the anti-oxidative stress enzymes from microbial as well as plant sources. The present investigation was carried out to test the anti-oxidative potential of medicinally important species of Pleurotus growing in the region.

\section{Materials and Methods}

\section{Collection and processing of mushroom samples}

Different Pleurotus sp viz Pleurotus ostreatus, Pleurotus djamor var. Roseus and Pleurotus florida and Pleurotus djamor var. roseus were procured from vikas benal mushroom farm, thakur mushroom farm and Directorate of mushroom research (DMR, Solan) respectively located in Himachal Pradesh, India. Pleurotussamples were morphologically analysedfor differences in colour, presence of scaling on their surface and characterized for anti-oxidative stress enzymes; SuperOxide Dismutase (SOD) and Peroxidase (POX).

Briefly, the collected Pleurotus samples were washed under tap water, surface sterilized (70\% ethanol) and stored at -20 ${ }^{\circ} \mathrm{C}$ for one week. The freeze-dried samples were homogenized in liquid nitrogen using mortar and pestle in three different freshly prepared buffer solutions (Phosphate citrate, Potassium 
phosphate, Tris- $\mathrm{HCl}$; $0.1 \mathrm{M}$ ) having $\mathrm{pH} 5.0$ to 9.0 respectively in the ratio of $1: 10(\mathrm{w} / \mathrm{v})$. Ultra -sonication of the homogenised samples was done (PUL 59, AMP1 32\%, Temp. $8{ }^{\circ} \mathrm{C}$ ) to obtain the maximum disruption of cells. Post-ultracentrifugation, the colloidal solution was centrifuged $(15,400 \mathrm{rpm}$ for $30 \mathrm{~min}$. at 4 ${ }^{\circ} \mathrm{C}$ ) to remove cell debris and the supernatant was used as crude enzyme solution for carrying out the enzyme assay.

All the chemicals were of high quality analytical grade and procured from Sigma (USA), Merck (Germany) and Hi-Media (India).

\section{Preparation of solvent extracts and quantitative determination of anti-oxidative stress enzymes}

Pleurotus samples were dried at $27{ }^{\circ} \mathrm{C}$ for $24 \mathrm{hrs}$. and grounded to powder using mortar and pestle. The extraction was done using different mushroom sample with three different solvent (methanol, ethanol and water) under the shaking conditions $(150 \mathrm{rpm})$ in the ratio of 1:10 (w/v) for 24 to $48 \mathrm{hrs}$. at $30{ }^{\circ} \mathrm{C}$. The mixture was filtered and the assay of anti-oxidative stress enzymes i.e. superoxide dismutase (SOD) and (POX) was performed in solvent extracts, supernatant and pellet.

Super Oxide Dismutase (SOD) assay based on the generation of the superoxide radicals in PMS-NADH systems by oxidation of NADH [5]. Briefly, one-unit SODenzyme activity (U) is that amount of enzyme required for $50 \%$ inhibition of NBT reduction in one minute at $560 \mathrm{~nm}$ under assay conditions. Similarly, one-unit peroxidase (POX) activity isthe amount of peroxidase required for the conversion of substrate $(1 \mu \mathrm{M})$ per minute under assay conditions [6] and involved O-PhenyleneDiamine (OPD) (chromogen) and hydrogen peroxide (H2O2) as substrate.

\section{Optimization of assay conditions for intracellular superoxide dismutase and peroxidase}

\section{Optimization of buffer and pH for homogenization}

The most suitable buffer and $\mathrm{pH}$ was determined by utilizing three different buffer systems namely phosphate citrate (1M; $\mathrm{pH}$ 5.0-8.0), potassium phosphate (1M; $\mathrm{pH} 6.0-8.0)$ and Tris- $\mathrm{HCl}$ (1M; pH 8.0-9.0) for homogenization of sample and measuring enzyme activity in each case.

\section{Effect of incubation temperature, time and enzyme concentration}

The effect of incubation temperature and time on the enzyme activity was evaluated by varying the range of temperature $\left(20,25,30,35,40\right.$ and $\left.45^{\circ} \mathrm{C}\right)$ for SOD, $\left(25-45^{\circ} \mathrm{C}\right)$ for POX and incubation time (80-105 second) for SOD, incubation time (5-30 min) and enzyme was assayed in both cases. The influence of reaction volume on enzyme activity was observed by varying the volume of crude enzyme $(100 \mu \mathrm{l}-500 \mu \mathrm{l})$ and enzyme assay done in each case.

\section{Results and Discussion}

Three different species of Pleurotus i.e. Pleurotus ostreatus, Pleurotus florida and Pleurotus djamor var. roseus showed distinct morphological characteristics of whitish color, white grey color and pink color respectively. Samples were processed using different solvent extracts and screened for two intracellular antioxidative enzymes superoxide dismutase (SOD) and peroxidase (POX).

\section{Solvent extract of enzyme}

The different samples subjected to various solvent extracts showed maximum SOD activity and POX activity. In ethanolic extract, Pleurotus djamor var. Roseus showed maximum (23.71U/mg) activity, followed by Pleurotus florida and (22.09 $\mathrm{U} / \mathrm{mg}$ ) in methanolic extract. Ramkumar et al. [7] reported that the methanol extraction of Pleurotus strains had the highest antioxidant activity. Free radical scavenging potential of ethanolic extract recorded for Pleurotus djamor var. roseus (90.74\%) was found to be comparable to Pleurotus pulmonarius extract (90\%) as reported earlier [8]. Similarly, ethanolic extract of Pleurotus djamorvar. Roseus and methanolic extract of Pleurotus florida showed $(0.47 \mathrm{U} / \mathrm{ml})$ and $(0.35 \mathrm{U} / \mathrm{ml})$ POX activity respectively. However, aqueous extract emerged as poorest SOD and POX activity for Pleurotus djamorvar. roseus and Pleurotus florida. Methanolic extraction of Pleurotus florida exhibited (84.97\%) potent superoxide radical scavenging activities which is similar to that reported earlier by Jose and Janardhanan [9]. Antioxidant mechanisms of the Pleurotus species extract; Pleurtus ostreatus (84.52\%), Pleurotus djamor var. roseus $(90.74 \%)$ and Pleurotus florida $(84.97 \%)$ attributed by hydrogen-donating and superoxide, free radicals scavenging ability [10].

\section{Effect of ultra-sonication on SOD activity}

After 5 cycles of ultra-sonication, Pleurotus djamor var. Roseus reported two-fold increases in SOD activity to maximum $26.70 \mathrm{U} / \mathrm{mg}$ protein.

\section{Standardization of different reaction parameter for SOD and POX}

Maximum enzyme activity was observed in Pleurotus djamor var. roseus and Pleurotus florida whereas Pleurotus ostreatus showed minimum activity. Therefore, these were selected for the optimization of reaction parameters for superoxide dismutase (SOD) and peroxidase (POX) enzymes.A comparison of the results of the previous and the present investigations on Pleurotus species showed that the intracellular antioxidative stress enzymes are variably secreted among the different species[11].

\section{Buffer system and $\mathrm{pH}$}

Among the three-buffer system (1M), namely potassium phosphate, phosphate citrate and Tris- $\mathrm{HCl}$ with varied $\mathrm{pH}$ [5-9], maximum SOD activity was recorded at $\mathrm{pH} 6.0$ with potassium phosphate buffer in case of P. djamor var. Roseus $(26.70 \mathrm{U} / \mathrm{mg})$ while for optimum SOD activity for P. florida, pH 6.5 (phosphate citrate buffer) resulted best with 22.12 activity units. Ramkumar et al. [7] has also recorded 20.29U/mg of SOD and 4U/mg of POX in dried samples of P. djamor. Increasing $\mathrm{pH}$ beyond 6.5 for all three buffers, showed a sharp decline in SOD activity. 
For POX activity in three different buffer systems with $\mathrm{pH}$ ranging from 5-10, Pleurotus djamor var. Roseus reported maximum POX activity $(0.51 \mathrm{U} / \mathrm{ml})$ with potassium phosphate buffer (1M, pH 6.0), followed by phosphate citrate $0.39 \mathrm{U} / \mathrm{ml}$ at $\mathrm{pH}$ 6.5. The activity of peroxidase enzyme in case of P. florida was recorded highest $(0.39 \mathrm{U} / \mathrm{ml})$ at $\mathrm{pH} 6.5$ with phosphate citrate buffer. Tris-HCl showed least activity SOD and POX activity $(0.22 \mathrm{U} / \mathrm{ml})$ in the three buffer systems with both samples of Pleurotus tested.

\section{Effect of incubation temperature and time}

Pleurotus spp. was subjected to varying temperature ranged from $20-45^{\circ} \mathrm{C}$ to estimate the SOD activity. Temperature range from $30-45^{\circ} \mathrm{C}$ was found to be suitable for optimum SOD enzyme activity, with maximum at $40{ }^{\circ} \mathrm{C}$ for P.djamor var. roseus and P. florida i.e. $29.95 \mathrm{U} / \mathrm{ml}$ and $22.74 \mathrm{U} / \mathrm{ml}$ respectively. However, any variation in temperature (below and above $40{ }^{\circ} \mathrm{C}$ ) resulted in decline in enzyme activity. Pleurotus djamor var. Roseus and Pleurotus floridaexhibit maximum POX activity of $0.63 \mathrm{U} / \mathrm{ml}$ and $0.46 \mathrm{U} / \mathrm{ml}$ respectively at $37{ }^{\circ} \mathrm{C}$ when subjected to temperature range of $\left(25-45^{\circ} \mathrm{C}\right)$. A sharp decline in POX activity was recorded beyond $37^{\circ} \mathrm{C}$. Different time intervals for SOD (80-105 sec) and POX (5-30 min) were tested to determine the time dependent activity of SOD and POX. The maximum SOD activity for Pleurotus djamor var. roseus (27.24U/mg) and Pleurotus florida (23.29U/ $\mathrm{mg}$ ) was recorded at 90 seconds and 100 seconds respectively. However, Pleurotus djamor var. Roseus showed maximum POX activity $(0.59 \mathrm{U} / \mathrm{ml})$ at $15 \mathrm{~min}$ and Pleurotus florida gave maximum activity of $0.42 \mathrm{U} / \mathrm{ml}$ after 20 minutes of incubation. Further decrease in SOD and POX activity was reported with increase in incubation time.

\section{Effect of enzyme concentration}

The concentration of enzyme used in the reaction mixture has its own significance in converting the substrate into the product and therefore influence the activity of SOD and POX. The crude enzyme extract from Pleurotusdjamorvar.roseus showed 27.59U/mg SOD activity at concentration of $300 \mu \mathrm{l}$ whereasPleurotusflorida showed $24.09 \mathrm{U} / \mathrm{mg}$ activity with $400 \mu \mathrm{l}$ crude enzyme extract. Further purification/processing may attribute to higher enzyme activity. The crude enzyme from Pleurotusdjamor var. roseus showed $0.72 \mathrm{U} / \mathrm{ml}$ POX activity at $70 \mu \mathrm{l}$ concentration followed by 0.59 activity units in Pleurotusfloridaat $90 \mu \mathrm{l}$. A further increase in volume of crude mushroom extract resulted in abrupt decline in the POX activity. The high inhibition value of Pleurotus may be due to the high phenolic residues in the extracts [12].

\section{Conclusion}

In this work, variable results were observed in Pleurotus species (Pleurotuso streatus, Pleurotus djamor var. roseus and Pleurotus florida) for the extraction of intracellular antioxidative enzymes (Superoxide dismutase and Peroxidase) using different parameters. Solvent extracts, homogenization with buffer systems of Pleurotus spp. with or without ultrasonication showed different levels of SOD activity and inhibition patterns of NBT reduction causing variable inhibition. Anti-oxidative stress enzymes (SOD and POX) revealed maximum activity in ethanolic extract of Pleurotus djamorvar. roseus with potassium phosphate buffer followed by methanolic extract of Pleurotus florida with phosphate citrate buffer. Maximum SOD $(26.70 \mathrm{U} / \mathrm{mg})$ and POX $(0.51 \mathrm{U} / \mathrm{ml}$ ) was recorded at $\mathrm{pH} 6.0$ (potassium phosphate buffer, $1 \mathrm{M})$ with P. djamor var. roseus and $(22.12 \mathrm{U} / \mathrm{mg})$ and $(0.39 \mathrm{U} /$ $\mathrm{ml}$ ) for P. Florida (phosphate citrate buffer, pH 6.5). The levels of anti-oxidative enzymes as reported in the present work are quite encouraging and indicate their usefulness for such enzymes, but more efforts and extensive studies are needed to derive and to reach a definite conclusion.

\section{Acknowledgement}

The authors are grateful to the Department of Biotechnology, Himachal Pradesh University, Shimla, India for the financial support and laboratory facility.

\section{References}

1. Yang JH, Lin HC, Mau JL (2002) Antioxidant properties of several commercial mushrooms. J Agric Food Chem 50(21): 6072-6077.

2. Mattila P, Salo V, Ananen P, Onko OK, Aro H, et al. (2002) Basic composition and amino acid contents of mushrooms cultivated in Finland. J Agric Food Chem 50(22): 6419-6422.

3. Kues U, Liu Y (2000) Fruiting body production in basidiomycetes. Applied Microbiology and Biotechnology 54(2): 141e152.

4. Endo A (1988) Chemistry, biochemistry, and pharmacology of HMGCoA reductase inhibitors. Klinische Wochenschrift. 66(10): 421-427.

5. Kakkar P, Das B, Viswanathan PN (1984) A modified spectrophotometer assay of superoxide dismutase. Indian J Biochem Biophys 21(2): 130-132.

6. Mahadevan R, Sridhar (1982) Methods in Physiological Plant Pathology, ( $\left.2^{\text {nd }} e d n\right)$, Sivakami Publications, Madras, India.

7. Ramkumar L, Ramanathan T, Thirunavukkarasu P, Arivuselvan $\mathrm{N}$ (2010) Antioxidant and radical scavenging activity of nine edible mushrooms extract. International journal of Pharmacology 6(6): 950-953.

8. Adebayo EA, Oloke JK, Ayandele AA, Adegunlola CO (2012) Phytochemical, antioxidant and antimicrobial assay of mushroom metabolite from Pleurotus pulmonarius -LAU09 (JF736658) Journal of Microbiology and Biotechnology Research 2(2): 366-374.

9. Jose N, Janardhanan KK (2000) Antioxidant and antitumour activity of Pleurotus florida. Curr Sci 79 (7): 941-943.

10. Keles A, Koca Í, Genccelep H (2011) Antioxidant properties of wild edible mushrooms. J Food Process Technol 2: 130.

11. Yim H S, Chye FY, Ho SK, Ho CW (2009) Phenolic profiles of selected edible wild mushrooms as affected by extraction solvent, time and temperature. Asian Journal of Food and Agro-Industry 2(03): 392401.

12. Turkoglu A, Mercan D, Nazime K, İbrahim G (2007) Antioxidant and antimicrobial activiti es of Laetiporus sulphureus (Bull.) Murril. Food Chemistry 101(1): 267-273. 


\section{Your next submission with Juniper Publishers} will reach you the below assets

- Quality Editorial service

- Swift Peer Review

- Reprints availability

- E-prints Service

- Manuscript Podcast for convenient understanding

- Global attainment for your research

- Manuscript accessibility in different formats ( Pdf, E-pub, Full Text, Audio)

- Unceasing customer service

Track the below URL for one-step submission https://juniperpublishers.com/online-submission.php 